\title{
Deciphering the vedolizumab dosing conundrum in IBD: when less is more
}

\author{
Timon Erik Adolph, ${ }^{1}$ Britta Siegmund (ㄱ) ${ }^{2}$
}

Already in the 1990s, the integrin $\alpha 4 \beta 7$, expressed on innate and adaptive immune cells, has been implicated in the control of lymphocyte recruitment to the intestinal mucosa. ${ }^{1}$ Pharmacological blockade of $\alpha 4 \beta 7$ with a monoclonal antibody, later termed vedolizumab, protected against spontaneous chronic colitis in the cotton-top tamarin model. ${ }^{2}$ Almost two decades later, phase III clinical trials in patients with IBDs proved vedolizumab efficacious for induction and maintenance of remission in $\mathrm{UC}^{3}$ as well as Crohn's disease (CD), ${ }^{4}$ which led to the drug approval by the European Medicines Agency in 2014. Only recently, the VARSITY trial indicated superiority of vedolizumab compared with adalimumab in UC with respect to clinical remission and endoscopic improvement, ${ }^{56}$ while at the same time displaying a favourable safety profile ${ }^{7}$ and the potential to predict treatment response (in CD) by a clinical scoring system. ${ }^{8}$ Notably, the initial reasoning for this therapeutic concept appeared rather clear; however, we are only beginning to appreciate its mechanisms of action. For example, characterisation of the mucosal and systemic immune cell compartment before and during vedolizumab treatment of 18 patients with IBD did reveal neither alterations in the abundance nor the receptor repertoire of mucosal $\mathrm{T}$ cells. Unexpectedly, vedolizumab rather resulted in profound effects on the innate immune system. ${ }^{9}$ A second study corroborated this notion by demonstrating that vedolizumab affected mucosal homing of non-classical monocytes, ${ }^{10}$ indicating that the immunomodulatory actions of vedolizumab are more diverse than previously anticipated. These findings were paralleled by the observation that vedolizumab efficacy is counterintuitively affected by dosing, in that higher trough concentrations appear to confer an unfavourable clinical

${ }^{1}$ Internal Medicine I, Medizinische Universitat Innsbruck, Innsbruck, Austria

${ }^{2}$ Medical Department I, Charite Universitatsmedizin Berlin Campus Benjamin Franklin, Berlin, Berlin, Germany

Correspondence to Dr Britta Siegmund, Medical Department I, Charite Universitatsmedizin Berlin Campus Benjamin Franklin, 12200 Berlin, Germany; britta.siegmund@charite.de response. $^{11} 12$ More specifically, these studies reported worse clinical outcomes in the highest dosage group (when compared with medium dosing), challenging the concept of intensified dosing due to a linear dose-response relation reported for other biologics in IBD, for example, anti-tumour necrosis factor- $\alpha$ $(\mathrm{TNF}-\alpha)^{13}$ or anti-interleukin (IL)-12/ IL-23 antibody therapy. ${ }^{14}$ Collectively, these studies emphasised the need for a better mechanistic understanding of vedolizumab efficacy in human IBD. The study by Becker et a $l^{15}$ in Gut deciphered aspects of this vedolizumab dosing conundrum.

The authors studied potential mechanisms by which this non-linear exposure efficiency of vedolizumab might be explained. They took advantage of fluorescently labelled vedolizumab, which was applied to bind and quantify peripheral human T-cell subsets from patients with IBD in vitro. By doing so, the authors noted that the concentration of vedolizumab influenced its binding to specific T-cell populations. Most notably, at $10 \mu \mathrm{g} /$ $\mathrm{mL}$, vedolizumab (reflecting the trough concentration with the most favourable clinical response in a phase II trial) targeted mostly effector $T$ cells $\left(T_{\text {eff }}\right)$ and less so regulatory $\mathrm{T}$ cells $\left(\mathrm{T}_{\text {reg }}\right)$, while $50 \mu \mathrm{g}$ / $\mathrm{mL}$ equally labelled both populations. In line, $10 \mu \mathrm{g} / \mathrm{mL}$ vedolizumab preferentially impaired adhesion and transmigration of $\mathrm{T}_{\text {eff }}$ when compared with $\mathrm{T}_{\text {reg }}$ (though with small effect size) in in vitro assays. As such, functional blockade of $\alpha 4 \beta 7$ with vedolizumab requires higher concentration for $\mathrm{T}_{\text {regs }}$ when compared with $\mathrm{T}_{\text {eff }}$. This is notable because $T_{\text {regs }}$ serve widely documented anti-inflammatory functions that allow to maintain gut homeostasis. ${ }^{16}$ In subsequent experiments, these data were confirmed in vivo in a humanised mouse model, demonstrating that $10 \mu \mathrm{g} / \mathrm{mL}$ vedolizumab preferentially blocked mucosal homing of $\mathrm{T}_{\text {eff }}$ when compared with $\mathrm{T}_{\text {reg }}$ in the mouse colon. To better understand this effect, free $\alpha 4 \beta 7$ binding sites were determined in the presence of ascending vedolizumab concentration in vitro and in $\mathrm{T}$ cells isolated from peripheral blood mononuclear cells of vedolizumab-treated patients. These experiments suggested that $10 \mu \mathrm{g} / \mathrm{mL}$ vedolizumab results in higher residual availability of $\alpha 4 \beta 7$ on $\mathrm{T}_{\text {reg }}$ than on $\mathrm{T}_{\text {eff }}$. To identify the $\alpha 4 \beta 7^{+}$ $\mathrm{T}$-cell population that is not targeted by vedolizumab, the authors performed flow cytometry sorting and single-cell sequencing of peripheral $\alpha 4 \beta 7^{+} \mathrm{T}$ cells (coexpressing $\mathrm{CD}^{+} \mathrm{CD} 45 \mathrm{RO}^{+}$) that were fluorescently labelled with vedolizumab ${ }^{+}$ or were unlabeled (vedolizumab ${ }^{-}$). These studies revealed a specific $\mathrm{T}_{\text {reg }}$ subpopulation expressing $\beta 1^{+} \mathrm{PI} 16^{+}$which was poorly targeted by vedolizumab at $10 \mu \mathrm{g} /$ $\mathrm{mL}$. Functional experiments on these purified $\beta 1^{+} \mathrm{PI}^{+} 6^{+} \mathrm{T}_{\text {reg }}$ cells confirmed reduced in vitro and in vivo binding to vedolizumab. Single-cell transcriptional profiling of $\beta 1^{+} \mathrm{PI} 16^{+} \mathrm{T}_{\mathrm{reg}}$ in the mucosa of vedolizumab-treated patients with IBD indeed demonstrated a pronounced regulatory phenotype. Vedolizumab trough concentration in patients with IBD indirectly correlated with free $\alpha 4 \beta 7$ binding sites in peripheral human $\mathrm{T}$ cells, which, however, was not observed for $\beta 1^{+} \mathrm{PI} 16^{+}$ $\mathrm{T}_{\text {reg }}$ cells, suggesting that the reported 'vedolizumab resistance' of this subpopulation is also found in patients with IBD. Finally, a post hoc analysis of the phase III trials in CD suggested that the optimal trough concentrations associated with clinical remission (at week 6) was in the range of $40-55 \mu \mathrm{g} / \mathrm{mL}$, while higher (or lower) trough concentrations were associated with poor outcome. Collectively, this study provides an explanation for the non-linear dose-response conundrum of vedolizumab, which inhibits residual homing of anti-inflammatory $\beta 1 \mathrm{PI} 16^{+} \mathrm{T}_{\text {reg }}$ at higher concentrations in IBD (figure 1). Whether these insights help to establish an ideal therapeutic window for vedolizumab in IBD warrants prospective controlled clinical trials.

Optimisation of immunosuppressive therapy in IBD is highly desirable due to poor long-term efficacy. ${ }^{17}$ As such, optimised dosing and therapy stratification of available therapeutics is a high priority. Remarkably, vedolizumab challenges the rather simple concept of dose intensification typically observed for anti-TNF- $\alpha$ antibodies or ustekinumab. Thus, the optimal therapeutic window for vedolizumab should be refined in prospective clinical trials, comparing intravenous with subcutaneous vedolizumab application. ${ }^{18}$ This appears particularly important because experimental data and clinical post hoc analysis of patients with $\mathrm{CD}$ from the GEMINI trials indicated a different range of this therapeutic window. Likewise, the mechanism of a vedolizumabresistant state of specific T-cell subsets is currently unresolved, which could pave 


\section{High vedolizumab concentration}

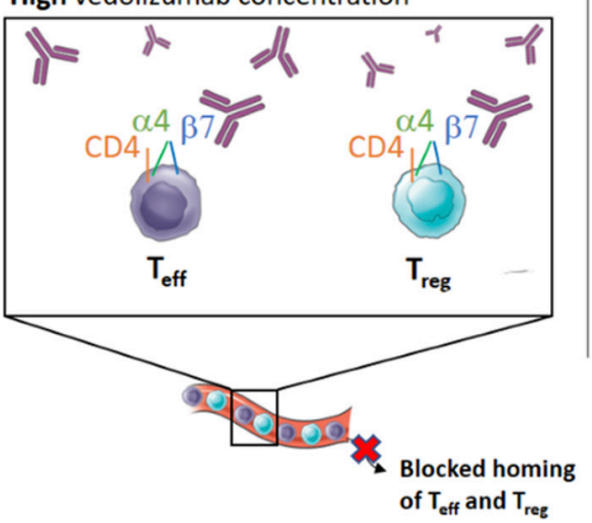

Intermediate vedolizumab concentration

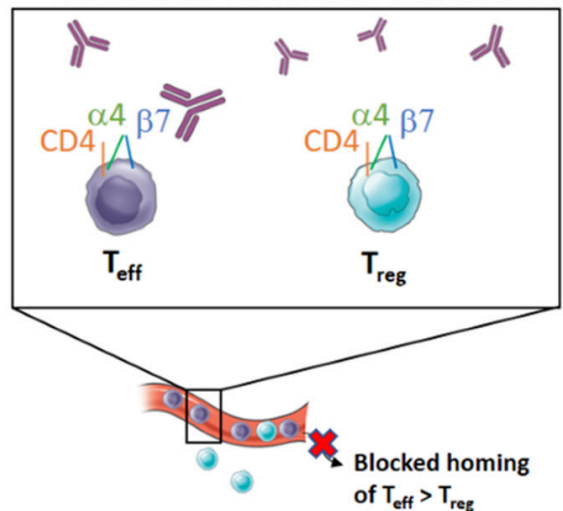

Figure 1 Vedolizumab concentration differentially affects $\alpha 4 \beta 7$ binding and homing efficacy of specific T-cell subsets in IBD. In the setting of a high vedolizumab serum concentration, $\alpha 4 \beta 7$ on $\mathrm{T}_{\text {eff }}$ and regulatory anti-inflammatory $\beta 1^{+} \mathrm{PI} 16^{+} \mathrm{T}$ cells $\left(\mathrm{T}_{\text {reg }}\right)$ is equally blocked and prevents gut homing. In the setting of intermediate vedolizumab serum concentration, $T_{\text {eff }}$ cell gut homing is prevented to a larger extend as compared with anti-inflammatory $\beta 1^{+} \mathrm{PI} 16^{+} \mathrm{T}_{\text {reg }}$ cells, which are poorly targeted by vedolizumab. This may explain why higher vedolizumab doses do not correspond with better clinical outcome, suggesting a tight therapeutic window for optimal efficacy. Notably, the optimal serum concentration of vedolizumab in IBD for clinical practice remains to be determined, similar to the mechanism for 'vedolizumab resistance' of $\beta 1^{+} \mathrm{PI}_{1}{ }^{+} \mathrm{T}_{\text {reg }}$ cells. $T_{\text {eff' }}$ effector $T$ cell; $T_{\text {reg' }}$ regulatory $T$ cell.

the way for boosting vedolizumab efficacy in IBD in the future. Thus, this study opens up new clinical perspectives and research questions. For example, does the reported observation hold true for patients with CD and UC alike, and is there a comparable window of opportunity in these disease entities? Moreover, considering alternative mechanisms of vedolizumab efficacy (on innate immunity), ${ }^{9} 10$ does dosing differentially affect homing of specific innate immune cell populations?

Collectively, this work beautifully exemplifies that we need to scratch deeper into gut immunology to appreciate the effects of targeted therapy on distinct immune populations in IBD. Understanding these mechanisms will be rewarding as this may also help to select patients for designated immunosuppressive therapy, to step into the era of individualised medicine.

Contributors TA and BS jointly discussed, structured and wrote the commentary.

Funding The authors have not declared a specific grant for this research from any funding agency in the public, commercial or not-for-profit sectors.

Competing interests $\mathrm{BS}$ has served as consultant for Abbvie, Arena, BMS, Boehringer, Celgene, Falk, Galapagos, Janssen, Lilly, Pfizer, Prometheus and Takeda, and received speaker's fees from Abbvie, CED Service GmbH, Falk, Ferring, Janssen, Novartis, Pfizer and Takeda (payments were made to the institution).

Patient and public involvement Patients and/or the public were not involved in the design, conduct, reporting or dissemination plans of this research.
Patient consent for publication Not required.

Provenance and peer review Commissioned; internally peer reviewed.

\section{0 \\ OPEN ACCESS}

Open access This is an open access article distributed in accordance with the Creative Commons Attribution Non Commercial (CC BY-NC 4.0) license, which permits others to distribute, remix, adapt, build upon this work non-commercially, and license their derivative works on different terms, provided the original work is properly cited, appropriate credit is given, any changes made indicated, and the use is non-commercial. See: http://creativecommons.org/ licenses/by-nc/4.0/.

(C) Author(s) (or their employer(s)) 2021. Re-use permitted under CC BY-NC. No commercial re-use. See rights and permissions. Published by BMJ.

\section{Check for updates}

To cite Adolph TE, Siegmund B. Gut Epub ahead of print: [please include Day Month Year]. doi:10.1136/ gutjnl-2021-325893

Received 22 August 2021

Accepted 31 August 2021

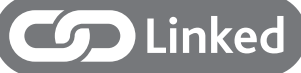

- http://dx.doi.org/10.1136/gutjnl-2021-324868.R1

Gut 2021:0:1-2.

doi:10.1136/gutjnl-2021-325893
ORCID iD

Britta Siegmund http://orcid.org/0000-0002-0055958X

\section{REFERENCES}

1 Berlin C, Bargatze RF, Campbell JJ, et al. Alpha 4 integrins mediate lymphocyte attachment and rolling under physiologic flow. Cell 1995;80:413-22.

2 Hesterberg PE, Winsor-Hines D, Briskin MJ, et al. Rapid resolution of chronic colitis in the cotton-top tamarin with an antibody to a gut-homing integrin alpha 4 beta 7. Gastroenterology 1996;111:1373-80.

3 Feagan BG, Rutgeerts P, Sands BE, et al. Vedolizumab as induction and maintenance therapy for ulcerative colitis. N Engl J Med 2013;369:699-710.

4 Sandborn WJ, Feagan BG, Rutgeerts P, et al. Vedolizumab as induction and maintenance therapy for Crohn's disease. N Engl J Med 2013;369:711-21.

5 Peyrin-Biroulet L, Colombel J-F, Colombel J-F, et al. Histologic outcomes with Vedolizumab versus adalimumab in ulcerative colitis: results from an efficacy and safety study of Vedolizumab intravenous compared to adalimumab subcutaneous in participants with ulcerative colitis (varsity). Gastroenterology 2021;160.

6 Sands BE, Peyrin-Biroulet L, Loftus EV, et al. Vedolizumab versus adalimumab for moderate-tosevere ulcerative colitis. N Engl J Med Overseas Ed 2019;381:1215-26.

7 Colombel J-F, Sands BE, Rutgeerts P, et al. The safety of vedolizumab for ulcerative colitis and Crohn's disease. Gut 2017;66:839-51.

8 Dulai PS, Boland BS, Singh S. Development and validation of a scoring system to predict outcomes of vedolizumab treatment in patients with crohn's disease. Gastroenterology 2018;155:687-95.

9 Zeissig S, Rosati E, Dowds CM, et al. Vedolizumab is associated with changes in innate rather than adaptive immunity in patients with inflammatory bowel disease. Gut 2019;68:25-39.

10 Schleier L, Wiendl M, Heidbreder K, et al. Non-classical monocyte homing to the gut via $\alpha 4 \beta 7$ integrin mediates macrophage-dependent intestinal wound healing. Gut 2020;69:252-63.

11 Feagan BG, Greenberg GR, Wild G, et al. Treatment of ulcerative colitis with a humanized antibody to the alpha4beta7 integrin. $N$ Eng/ J Med 2005;352:2499-507.

12 Parikh A, Leach T, Wyant T, et al. Vedolizumab for the treatment of active ulcerative colitis: a randomized controlled phase 2 dose-ranging study. Inflamm Bowel Dis 2012;18:1470-9.

13 Hanauer SB, Sandborn WJ, Rutgeerts P, et al. Human anti-tumor necrosis factor monoclonal antibody (adalimumab) in Crohn's disease: the CLASSIC-I trial. Gastroenterology 2006;130:323-33.

14 Feagan BG, Sandborn WJ, Gasink C, et al. Ustekinumab as induction and maintenance therapy for Crohn's disease. N Engl J Med 2016;375:1946-60.

15 Becker E, Dedden M, Gall C. Residual homing of $\alpha 4 \beta 7$-expressing $\beta 1^{+} \mathrm{P} 116^{+}$regulatory T cells with potent suppressive activity correlates with exposure-efficacy of vedolizumab. Gut 2021;142:gutjnl-2021-324868.

16 Barnes MJ, Powrie F. Regulatory T cells reinforce intestinal homeostasis. Immunity 2009;31:401-11.

17 Neurath MF, Travis SPL. Mucosal healing in inflammatory bowel diseases: a systematic review. Gut 2012;61:1619-35.

18 Sandborn WJ, Baert F, Danese S, et al. Efficacy and safety of Vedolizumab subcutaneous formulation in a randomized trial of patients with ulcerative colitis. Gastroenterology 2020;158:562-72. 